Vol. 1, 2019

\title{
Exitomania, the propaganda machine that can destroy the European Union
}

\author{
Assist. Prof. PhD. Tănase Tasențe \\ "Ovidius" University of Constanta, Romania \\ office@pluscommunication.eu \\ Prof. univ. dr. habil. Mihaela Rus \\ "Ovidius" University of Constanta, Romania \\ psiholog_m@yahoo.com
}

\begin{abstract}
Euroscepticism has worsened among the member countries, and an opinion poll conducted by the Pew Research Center, on a sample of 10,491 respondents from $10 \mathrm{EU}$ countries and published shows that in 2 member countries - France and Greece - $61 \%$ and $71 \%$ of the citizens regard the European Union in a negative sense. This unfavorable perception regarding the future of the European Union has spread and was immediately exploited by political parties from different countries that have been voted in the European Parliament. Thus, we can see that the Euro-Parliamentary groups with Eurosceptic ideologies started to grow fast and according to the configuration of the 2019 European Parliament, we can see that the eurosceptics gain more strength. Through this research, we set out to analyze the degree of online interest regarding keywords related to EU leaving, in 8 countries of the European Union: The Netherlands (Nexit), United Kingdom (Brexit), France (Frexit), Greece (Grexit), Ireland (Irexit), Spain (Spexit), Italy (Italexit) and Sweden (Swexit). In order to reach the research objectives, we collected the data on the online interest from the Google Trends website (the evolution over time regarding Euroscepticism in the European Union, the maps regarding the regions of the 8 countries monitored with the highest degree of online interest for "EU leaving", and the most searched keywords in each country regarding leaving the European Union). The monitoring period is January 2004 - July 2019.
\end{abstract}

Keywords. Google Trends, Euroscepticism, Exitomania, European Union, Brexit

\section{What is Euroscepticism and how has it spread in the media, online environment and in the European Parliament?}

Euroscepticism is a political ideology on skepticism about the European Union and, in general, to the concept of European integration. Sometimes, this concept is motivated by the desire to preserve the sovereignty and identity of nations instead of creating a European federal state, but most of the times, this ideology is used as a political tool, threatening and blackmailing every time. the idea of a country is not supported by the rest of the member countries.

The term "Euroskepticism" is a neologism adopted quickly and definitively by the media and the citizens of the European Union, and according to Michael Ray, the concept represents an "European political doctrine that advocates disengagement from the European Union (EU). Political parties that espouse a Eurosceptic viewpoint tend to be broadly populist and generally support tighter immigration controls in addition to the dismantling or streamlining of the EU bureaucratic structure"1. From

\footnotetext{
${ }^{1}$ https://eavi.eu/what-is-euroscepticism/
} 
another point of view, the Eurosceptic sentiment is generally based on two major causes: the economic crisis and the identity crisis.

Immediately the Referendum on Brexit, Euroscepticism has worsened among the member countries, and an opinion poll conducted by the Pew Research Center, on a sample of 10,491 respondents from 10 EU countries and published by the $\mathrm{BBC}^{2}$ shows that in 2 member countries - France and Greece $61 \%$ and $71 \%$ of the citizens regard the European Union in a negative sense. On the other hand, Euroscepticism has also spread in the UK (48\% view the EU unfavourable), Spain (49\%), Germany (48\%), The Netherlands (46\%), Sweden (44\%), Italy (39\%) and Hungary (37\%).

\section{How European countries view the EU}

\section{Unfavourable \% Favourable}

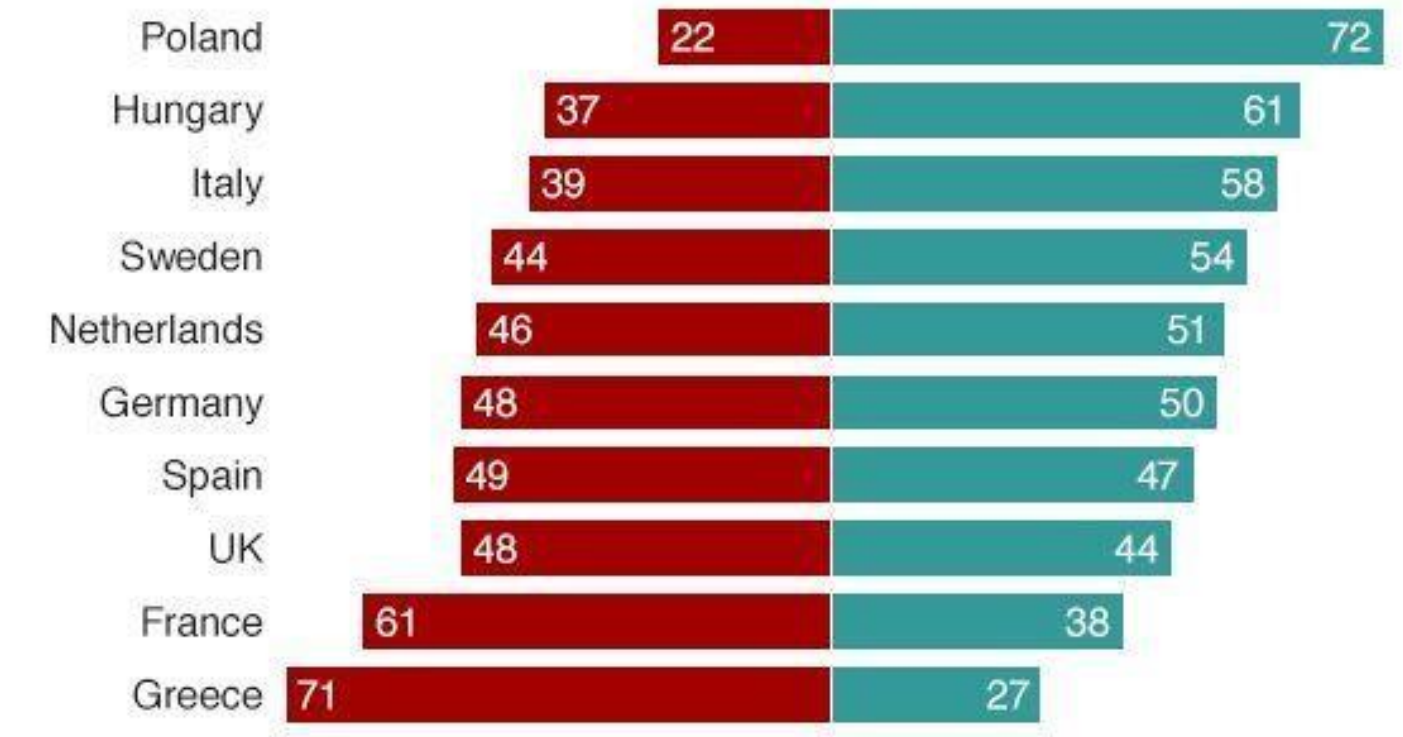

Source: Pew Research Center

Figure 1 - How European countries view the EU. Sourse: Pew Research Center

This unfavorable perception regarding the future of the European Union has spread and was immediately exploited by political parties from different countries that have been voted in the European Parliament. Thus, we can see that the Euro-Parliamentary groups with Eurosceptic ideologies started to grow fast. According to a 2014 Pew Research Center study, Euroskeptics "share jumped to $29 \%$, or 221 MEPs; it's now 30\%, due to membership changes and shifts in political groupings." UK delegations, in fact, Euroskeptics outnumber pro-EU members"3.

\footnotetext{
${ }^{2}$ https://www.bbc.com/news/uk-politics-eu-referendum-36471989

${ }^{3}$ https://www.pewresearch.org/fact-tank/2019/05/22/euroskeptics-are-a-bigger-presence-in-the-europeanparliament-than-in-past/
} 
Vol. 1, 2019

\section{Europeanist}
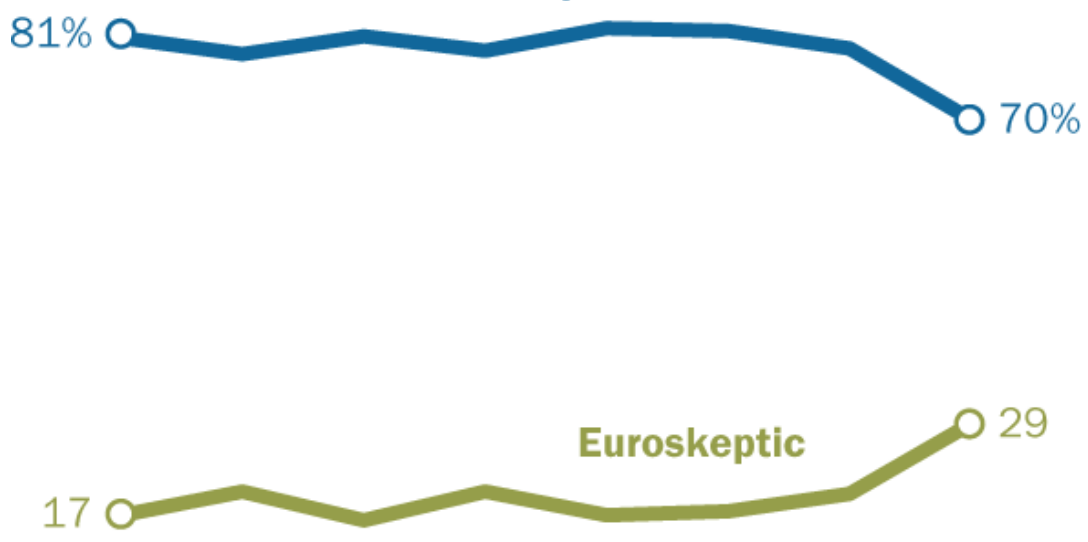

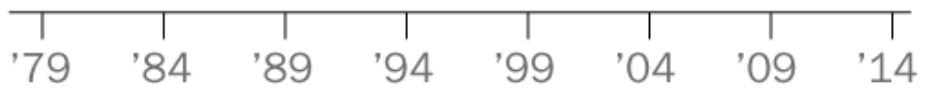

Figure 2 - Pew Research Center - Euroskepticism jumped in last European Parliament election

However, following the new configuration of the European Parliament, from 2019, we can see that the eurosceptics gain more strength compared to the political configuration of the 2014-2019 legislature. "Eurosceptic parties enjoyed their best ever results in the European elections on Sunday night as voters flocked in their millions to vote for populist parties and abandoned the two groups that have dominated EU politics for the last 40 years. A total of 169 MEPs were returned from eurosceptic parties across the EU, according to preliminary results based on exit polls and results. With the seats split between three separate political groups, the populists will be unable to directly alter the push for closer EU integration from the dominant Europhile parties. In the 2014 elections, 155 MEPs from antiEU parties were returned to the European Parliament)"4, says journalist James Crisp, in an article published in The Telegraph, titled "Eurosceptic parties reshape EU politics after strongest showing in European elections".

Moreover, the phenomenon of Euroscepticism has been propagated by the media and, in the online environment, through mass dissemination in Social Media, especially during the campaign for the European Parliament in 2019. At the same time, a British political marketing company - Cambridge Analytica - has been accused of misusing data from millions of Facebook profiles to target voters with online political messages to potential sway public opinion in the 2016 Brexit Referendum. Thus, Cambridge Analytica has officially supported both Leave.Eu and the United Kingdom Independence Party in the online campaign, after which $51.9 \%$ of voters have decided that the Great Britain will leave the European Union.

\section{Study on the degree of Euroscepticism manifested in the online environment}

\subsection{Research objectives and methodology}

Our aim is to analyze the degree of online interest regarding keywords related to EU leaving, in 8 countries of the European Union: The Netherlands (Nexit), United Kingdom (Brexit), France (Frexit), Greece (Grexit), Ireland (Irexit), Spain (Spexit), Italy (Italexit) and Sweden (Swexit). In order to reach the research objectives, we collected the data on the online interest from the Google Trends website (the evolution over time regarding Euroscepticism in the European Union, the maps regarding the

\footnotetext{
${ }^{4}$ https://www.telegraph.co.uk/politics/2019/05/26/eurosceptic-parties-reshape-eu-politics-strongest-showingeuropean/
} 
regions of the 8 countries monitored with the highest degree of online interest for "EU leaving", and the most searched keywords in each country regarding leaving the European Union). The monitoring period is January 2004 - July 2019.

\subsection{Centralization and data analysis}

In the 8 European countries analyzed, respectively UK, Netherlands, France, Greece, Ireland, Spain, Italy and Sweden, the feeling of Euroscepticism and of leaving the European Union has reached alarming levels, starting with 2015 and continuing until now. The EU-leave propaganda started in Spain, in June 2010, when the search score on Google of the term "Spexit" was 82/100. Periods of intense Google searches of Spanish citizens about leaving the European Union of Spain continued between April and July 2011, between April 2012 and January 2013 and between April and June 2014.

From October 2014 until July 2015, Euroscepticism manifested itself in the online environment and among the Greeks who questioned Google about Grexit (a term used for a possible leaving from the European Union of Greece. Since then, other countries have developed a strong feeling of Euroscepticism, Google search scores reaching 100/100, as follows: Swexit and Brexit (June 2016), Frexit (April 2017), Spexit (April 2018), Irexit (September 2018), Italexit (83/100 - October 2018 and 100/100 - June 2019) and again, Brexit (March 2019).

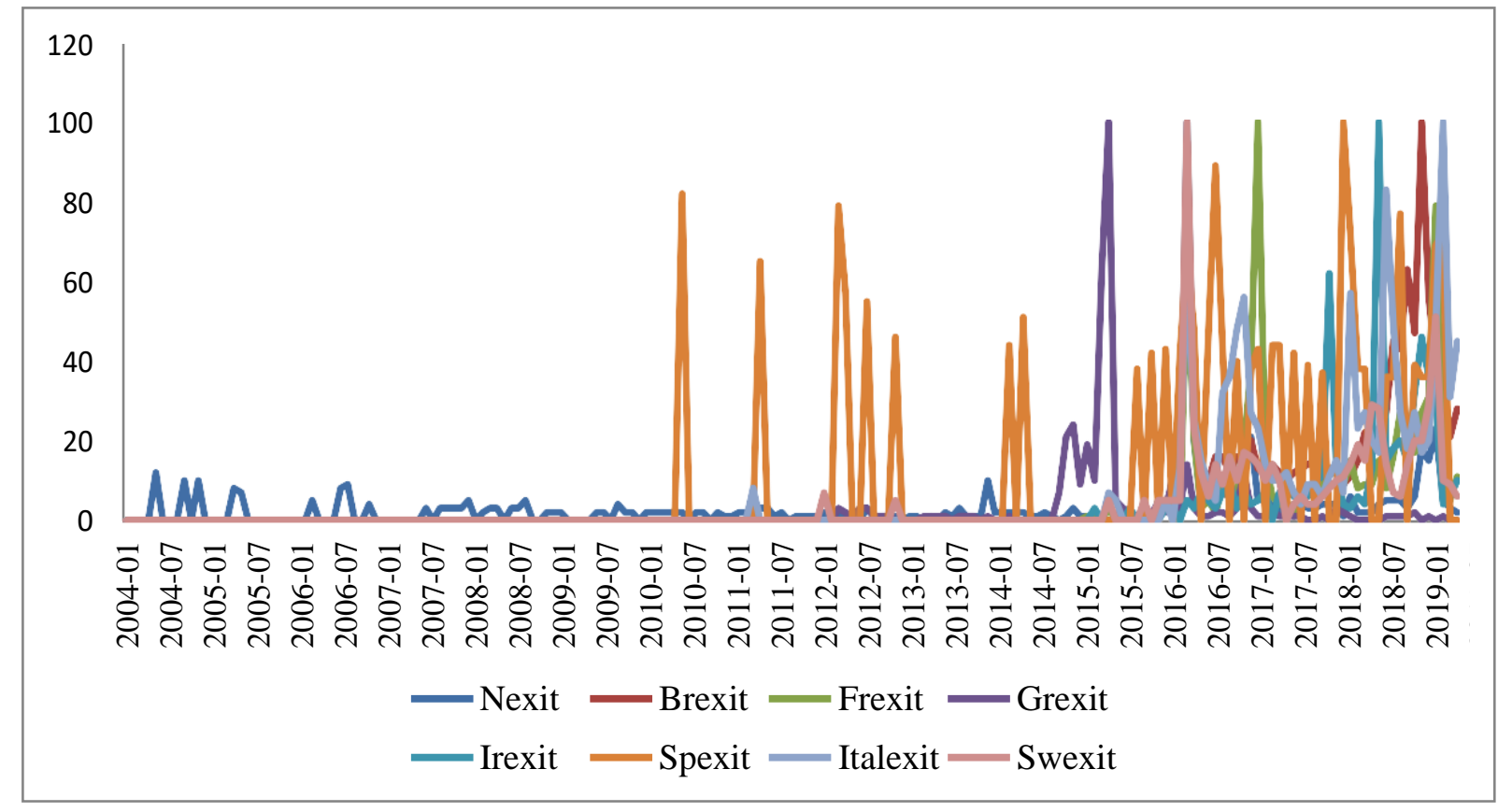

Figure 3 - The evolution of Euroscepticism in the online environment, by keywords on Google (20142019, Google Trends)

\section{The most frequently searched keywords on Google about leaving EU by countries}

\section{A. Nexit, in The Netherlands}

The regions in The Netherlands that showed the greatest online interest for Nexit are: Gelderland (100/100), Utrecht (75/100), Groningen (69/100), Overijssel (65/100) and the Province of Friesland (63 / 100). The most searched keywords in The Netherlands related to Nexit are: "Brexit", "Nexit Referendum", "Nexit Betekenis", "What is Nexit", "Nexit petitie", "fvd nexit", "nexit peiling" if "not nexit". 
Vol. 1, 2019

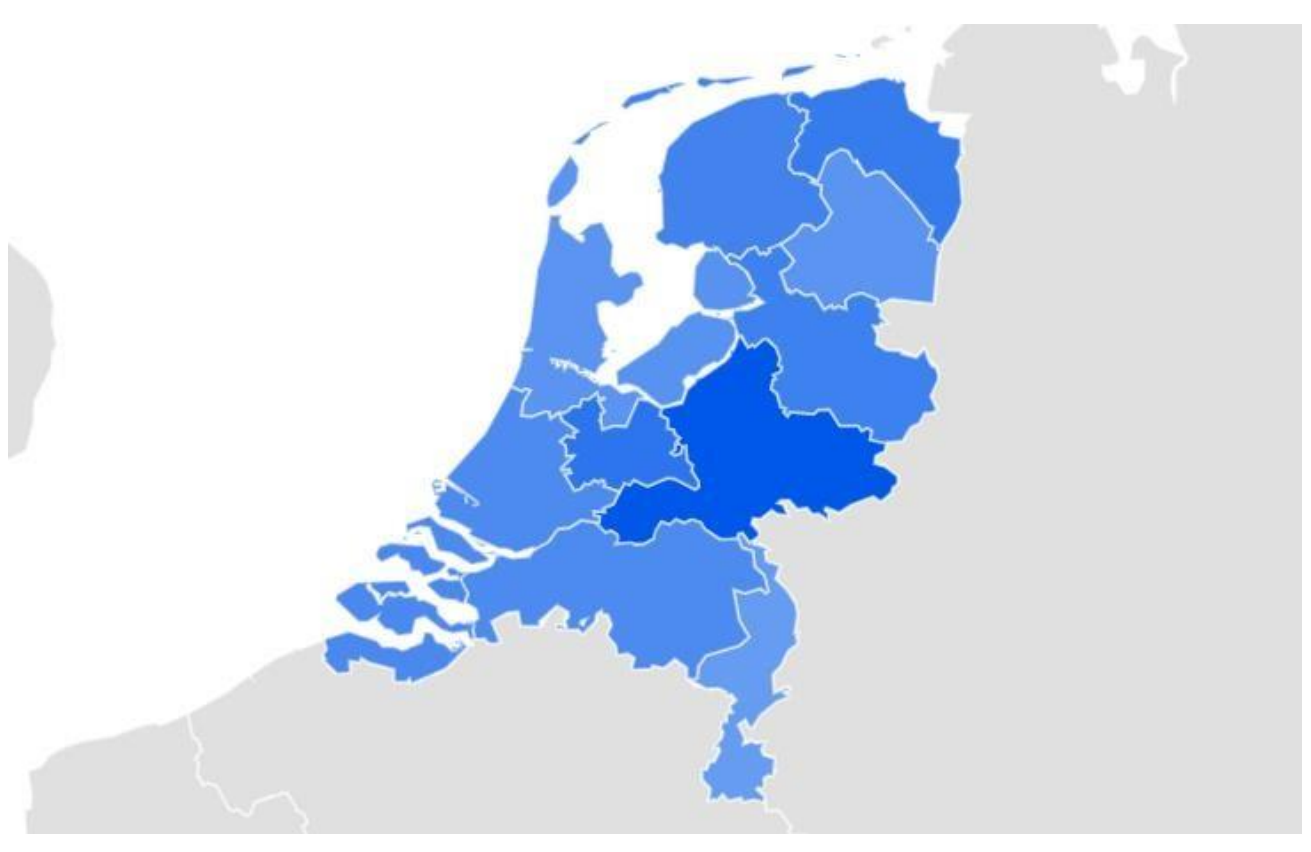

Figure 4 - Map of the Netherlands on the search for "Nexit"

\section{B. Brexit, in the United Kingdom}

The countries in the United Kingdom that have shown the greatest interest in Brexit online are: Northern Ireland (100/100), Wales (92/100), England (81/100) and Scotland (73/100). The most searched keywords in the UK related to Brexit are: "Brexit", "Brexit News", "Brexit Latest", "UK, "UK Brexit", "Eu Brexit", "BBC Brexit", "Brexit vote", "Brexit Deal", "Brexit Party" etc.

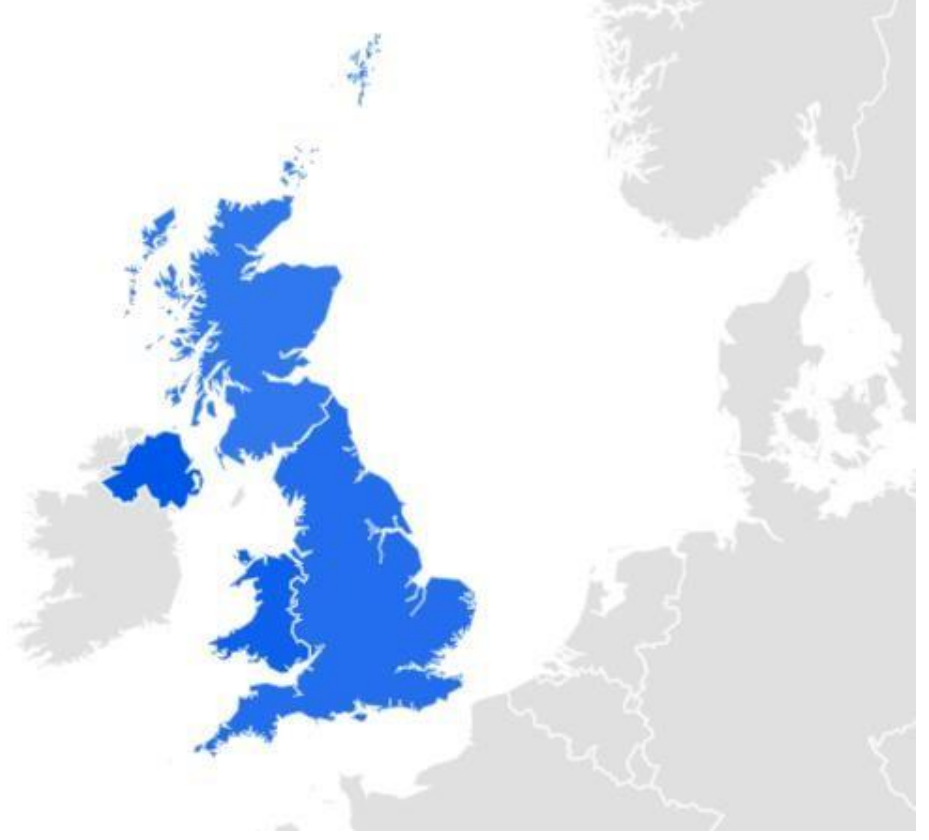

Figure 5 - Map of the UK on the search for "Brexit"

C. Frexit, in France 
Vol. 1, 2019

The regions in France that showed the greatest online interest for Frexit are: Franche-Comte (100/100), Limousin (99/100), Languedoc-Roussilon (99/100), Ron-Alpi (97/100), Midi-Pirinei (90/100), Aquitania (89/100), Poitou-Charentes (87/100), Pays de la Loire (86/100), Normandia de Jos (85/100), Center (85/100), Nord-Pas-de-Calais (83/100), Bretania (83/100), Lorena (81/100), Proventa-Alpi-Coasta de Azur (80/100) and Ile-deFrance (80/100). The most searched keywords in France related to Frexit are: "frexit", "le frexit", "brexit", "asselineau frexit", "asselineau", "frexit tv", "frexit sondage", "candidat frexit", "frexit definition", "macron frexit", "frexit 2019", "petition frexit" etc.

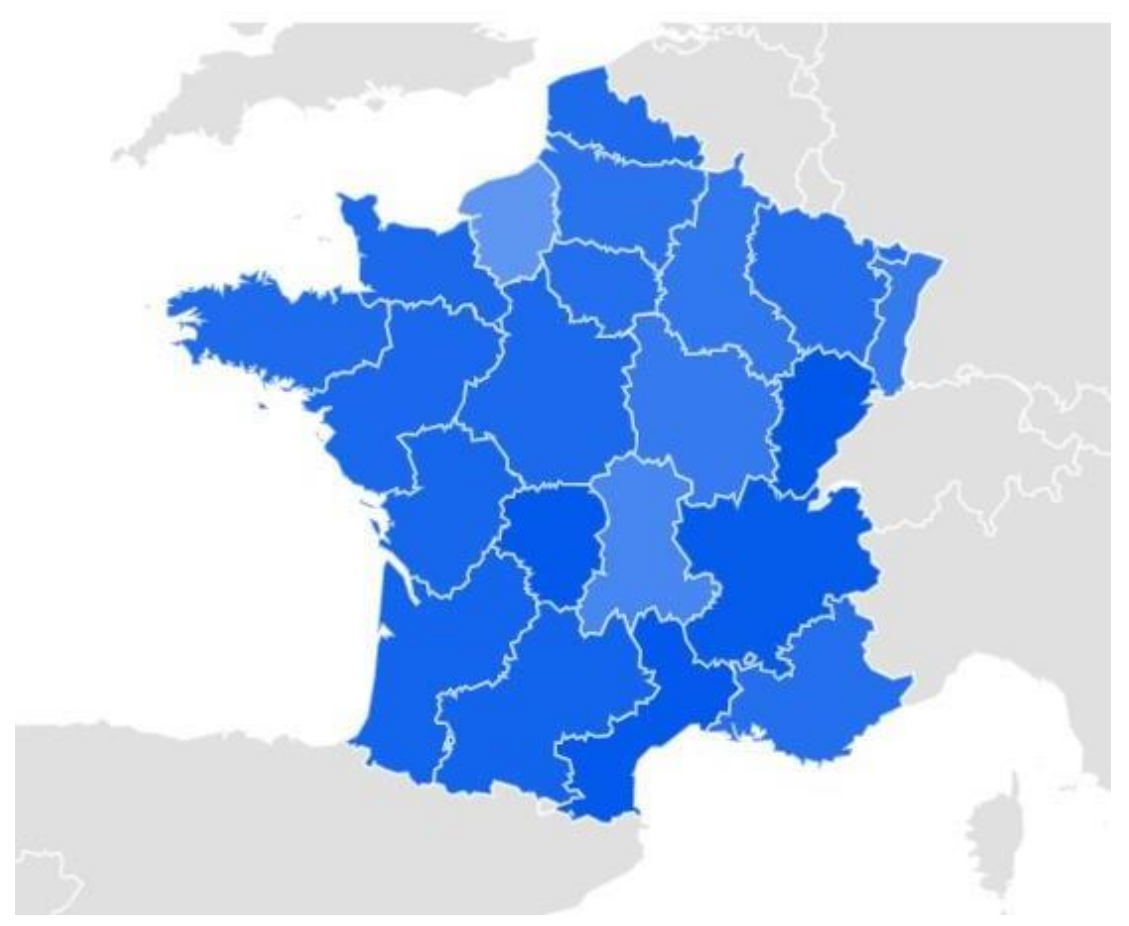

Figure 6 - Map of France on the search for "Frexit"

\section{Grexit, in Greece}

The regions in Greece that showed the greatest online interest for Grexit are: Athens (100/100) and Salonic (97/100). The most searched keywords in Greece related to Grexit are: " $\tau$ evval grexit",

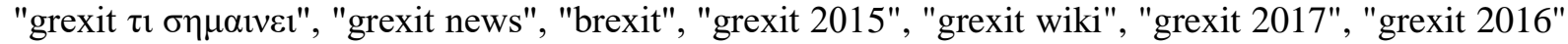
etc. 


\section{(1) TECHNIUM

Vol. 1, 2019

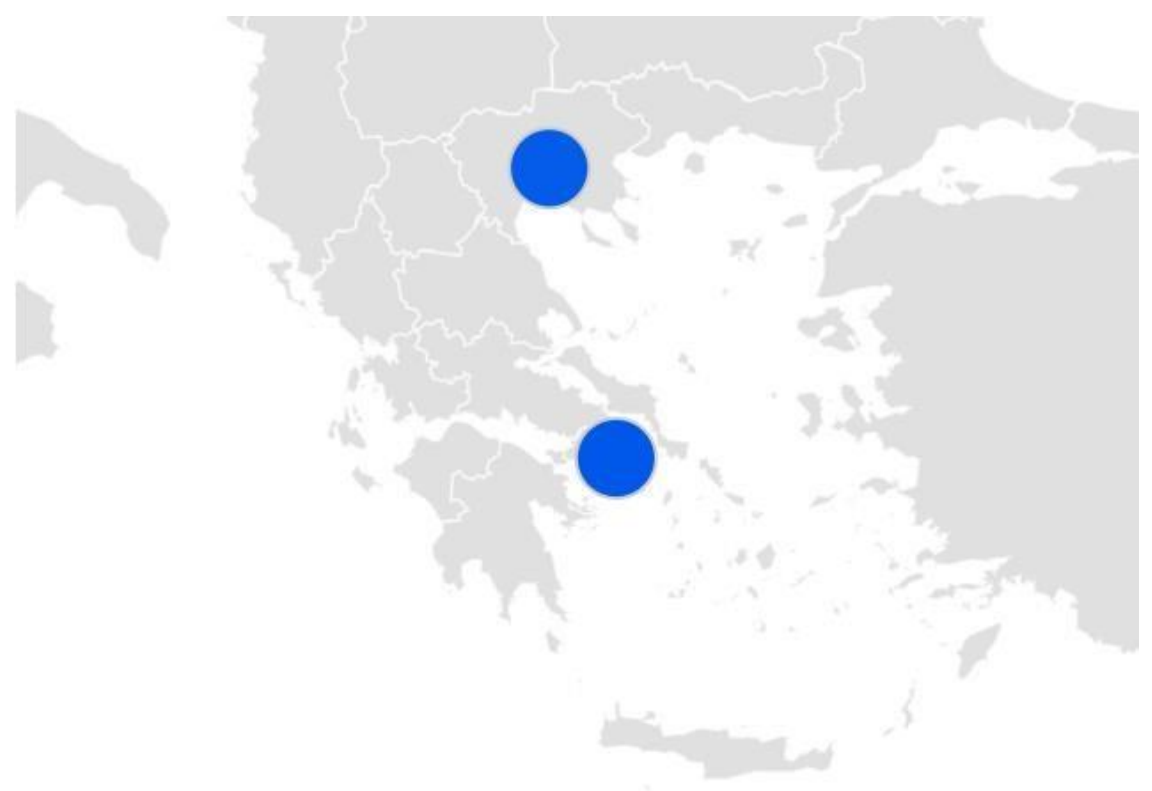

Figure 7 - Map of Greece on the search for "Grexit"

\section{E. Irexit, in Ireland}

The regions in Ireland that showed the greatest online interest for Irexit is Dublin (100/100) and the most searched keywords in Ireland related to Irexit are: "irexit party" and "irexit freedom party".

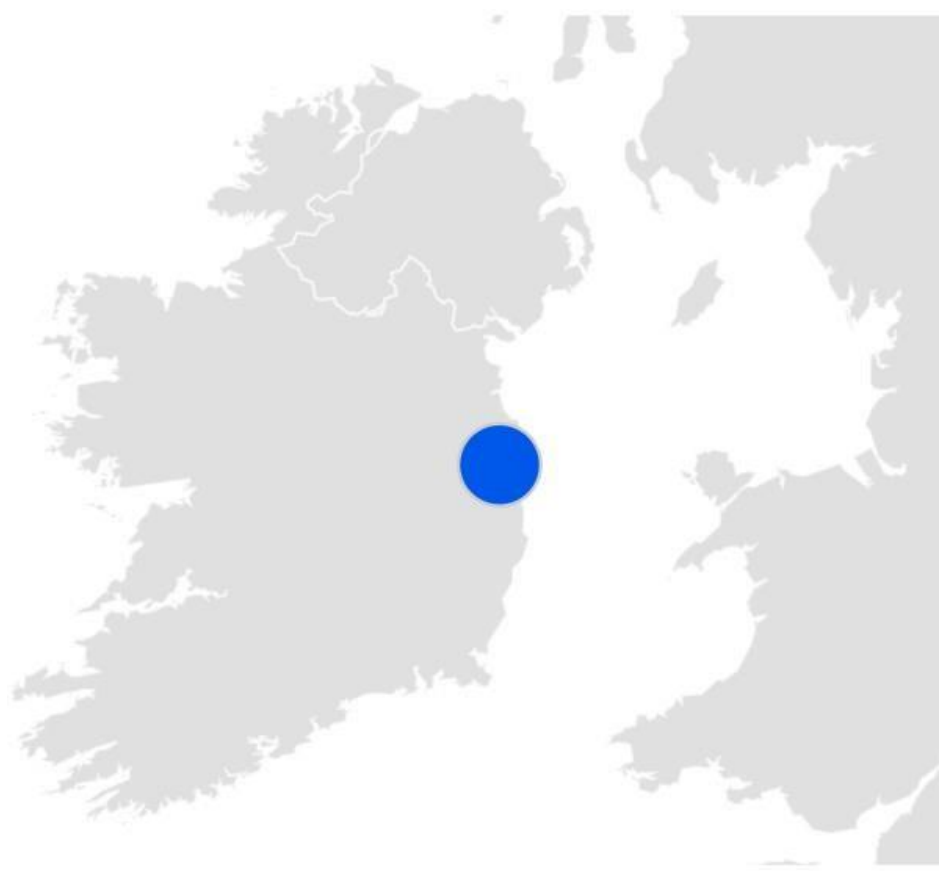

Figure 8 - Map of Ireland on the search for "Irexit"

F. Spexit, in Spain

The regions in Spain that showed the greatest online interest for Spexit are: Andaluzia (100/100), Catalonia (49/100), Valencian Comunity (49/100) and Madrid (37/100). The most searched keywords in Spain related to Spexit are: "spexit", "spain leaves eu", "brexit" etc. 
Vol. 1, 2019

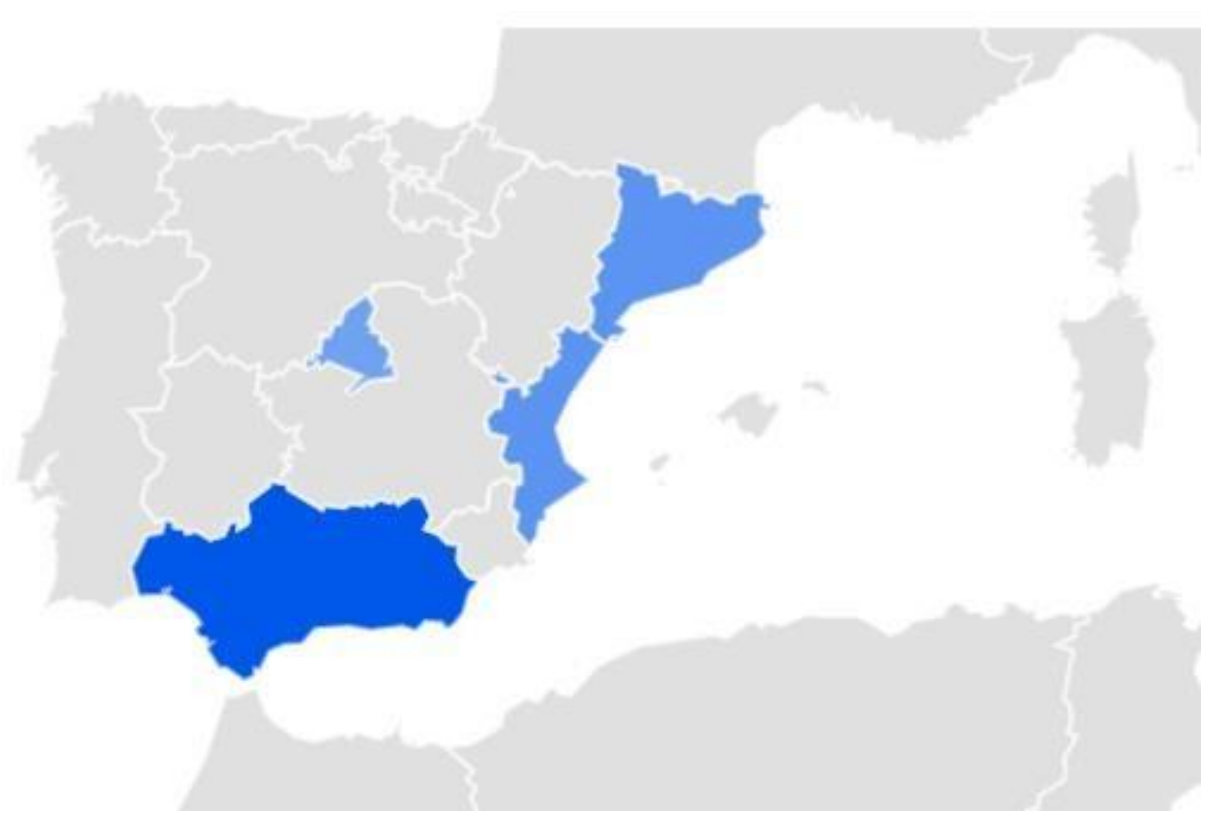

Figure 9 - Map of Spain on the search for "Spexit"

\section{G. Italexit, in Italy}

The regions in Italy that showed the greatest online interest for Italiexit are: Piemont (100/100), Toscana (97/100), Veneto (94/100), Lombaria (92/100), Emilia-Romagna (87/100), Liguria (84/100), Apulia (83/100), Campania (78/100), Sicilia (76/100) and Lazio (66/100). The most searched keywords in Italy related to Italexit are: "italexit", "italy leaves eu", "brexit" etc.

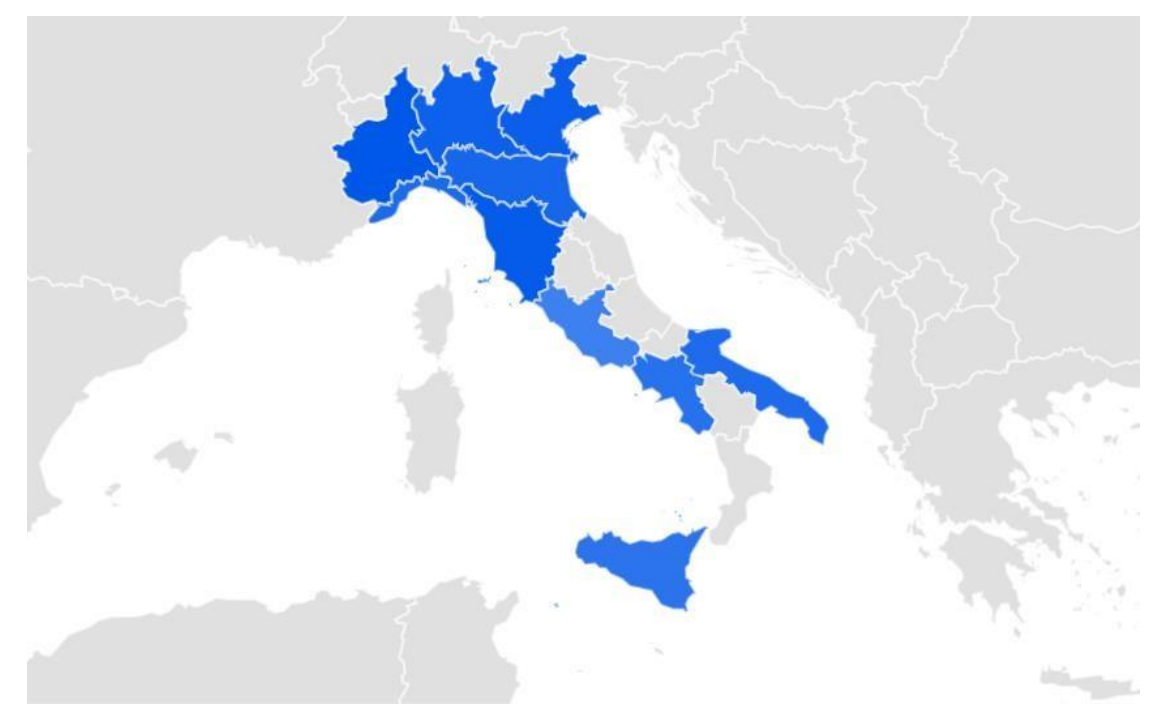

Figure 10 - Map of Italy on the search for "Italexit"

H. Swexit, in Sweden

The regions in Sweden that showed the greatest online interest for Swexit are: Värmlands län (100/100), Västerbottens län (92/100), Västernorrlands län (91/100), Uppsala län (86/100), Västra Götalands län (74/100). The most searched keywords in Sweden related to Swexit is: "brexit" 


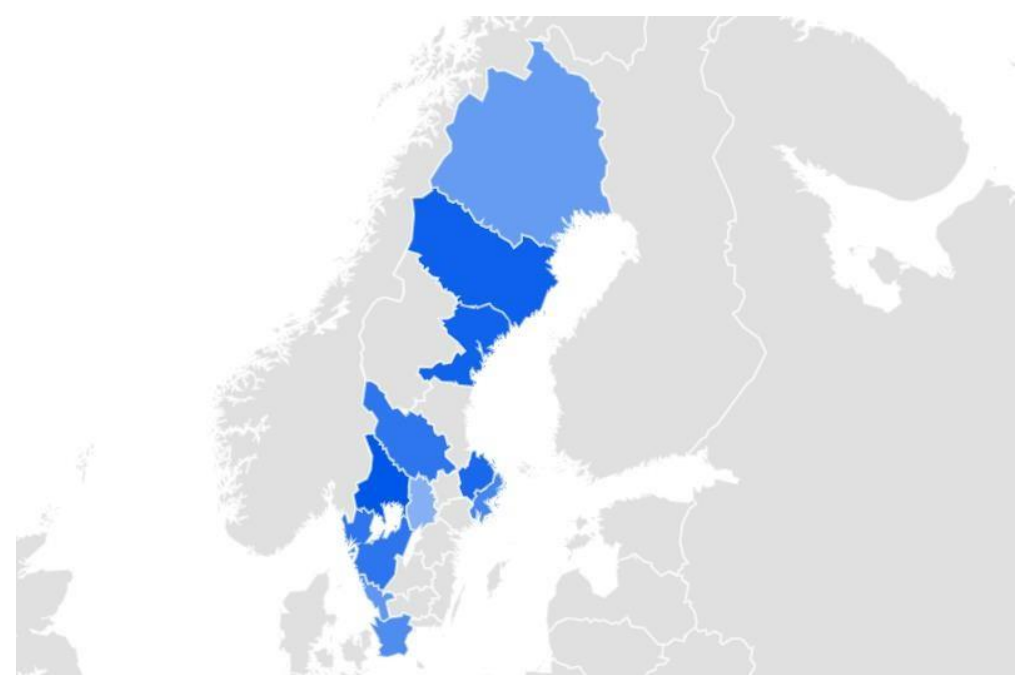

Figure 11 - Map of Sweden on the search for "Swexit"

\section{Conclusions}

The phenomenon of Euroscepticism (Exitomania, as we called it) has spread a lot in the last 5 years, in the online environment, especially through mass media articles and through mass dissemination in Social Media (Facebook, Twitter, Youtube, etc.). All this propaganda machine has had an effect on the citizens of the EU member states with a greater predisposition towards Euroscepticism (eg UK, Netherlands, France, Greece, Ireland, Spain, Italy or Sweeden), which will most likely lead to serious damage to European identity construction.

Moreover, we could see that the phenomenon of Euroscepticism proliferated also through political propaganda, many parties with Eurosceptic political ideologies entered the European Parliament and formed very vocal political groups, both in the plenary of the parliament, but especially in the media. and on social media. In 2019, Eurosceptic parties enjoyed their best ever results in the European elections as voters flocked in their millions to vote for populist parties and abandoned the two groups that have dominated EU politics for the last 40 years and a total of 169 MEPs were returned from eurosceptic parties across the EU

According to a study we conducted on a sample of $8 \mathrm{EU}$ member countries, we found that the first online manifestations on Euroscepticism were in July 2010, when a very large percentage of Internet users in Spain were searching on Google for the term by "Spexit", the trend that continued, with slight interruptions, and between 2011 and 2019. The next country that manifested itself online pro-exit from the European Union was Greece (January - July 2015). Since then, a strong wave of Euroscepticism has spread among citizens from several countries, such as: United Kingdom (June 2016), France (April 2017), Spain (April 2018), Ireland (September 2018), Italy (October 2018) - June 2019).

After analyzing the keywords from Google, we could see that the wave of the Exitomania phenomenon was particularly affected by the Brexit Referendum, many Google searches ("nexit", "frexit", "grexit", italexit "," spexit ", irexit ", swexit") being in correlation with the key term "brexit".

\section{References}

[1] https://eavi.eu/what-is-euroscepticism/

[2] https://www.bbc.com/news/uk-politics-eu-referendum-36471989 
Vol. 1, 2019

[3] https://www.pewresearch.org/fact-tank/2019/05/22/euroskeptics-are-a-bigger-presence-in-theeuropean-parliament-than-in-past/

[4] https://www.telegraph.co.uk/politics/2019/05/26/eurosceptic-parties-reshape-eu-politics-strongestshowing-european/ 